technical terms used are clearly stated and listed, and nine appendixes in which detailed discussions are given of proposed units and measurement procedures. The following are dealt with in particular : the choice of the units for radiation intensity (watt. $\mathrm{cm}^{2}$ ) and for dose (erg/gm.), thus avoiding the use of the roentgen; the choice of a radiation-intensity secondary standard; a 5-cm. thick 'Lucite' cover for the sensitive element of a survey instrument; and the recommendation for high-energy installations of the standard personnel-monitoring procedures at present in use for radiations of less than $2 \mathrm{MeV}$.

United States Unclassified Material on Atomic Energy

THE United States Atomic Energy Commission has named the Stanford Research Institute, California, as one of three national industrial information depositories of unclassified information concerning developments in the field of atomic energy, the other two depositories being the Atomic Industrial Forum of New York and the John Crerar Library of Chicago. The Stanford Research Institute will serve particularly the western States and Hawaii and Alaska, by maintaining the collection and providing library, reference, photocopy and literature-search services to public interests. It has recently received an initial complement of materials consisting of seven hundred reports of industrial interest selected from 9,500 'basic science' reports filed with the Atomic Energy Commission, as well as a set of reproductions of drawings for a 'swimming pool' reactor, all the back issues of Nuclear Science Abstracts and sets of bibliographies of selected reports of value to industry. Mr. William A. Casler has been appointed to take charge of the depository. In December 1952 the Institute opened a Radiation Engineering Laboratory for industrial research with radioactive materials, the source of cobalt- 60 provided to the Laboratory by the Atomic Energy Commission being the largest released for such use at the time. The previous year the Institute published results of a study sponsored by the Commission on "Industrial Uses of Radioactive Fission Products".

Financial Estimates for the Department of Scientific and Industrial Research

IN reply to further questions in the House of Commons on July 27, the Parliamentary Secretary to the Ministry of Works, Mr. J. R. Bevins, stated that the published estimate of $£ 6 \cdot 25$ million for the Department of Scientific and Industrial Research for the present financial year represented an increase of

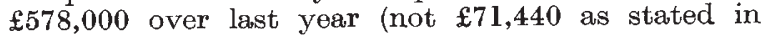
Nature, August 7, p. 251), of which $£ 230,000$ was part of the projected expansion by $£ 900,000$ over five years. The gross expenditure had increased from $£ 5.8$ million in 1952 to $£ 7$ million in the present year. The non-industrial staff, 3,108 on July 1,1954 , compared with 2,500 in 1949 , would be increased to 3,900 in 1959 , when the general level of activity would be 95 per cent of that projected in the expansion plans of 1947-48. At present the cost of the research on sulphate-reducing bacteria, on which twelve people were engaged at the Chemical Research Laboratory, was about $£ 13,000$ a year, and that of the work on corrosion of buried pipes, on which six people were engaged, about $£ 6,000$ a year. Studies of marine bacteriology, smoke curing, hygiene of fish handling and freezing at the Torry Research Station were at present held up on account of insufficient staff and inadequate buildings. On
July $30 \mathrm{Mr}$. Bevins also stated that during the period April 1946-July 1954 the Department had made grants totalling $£ 1,621,700$ to the universities for the construction of high-energy particle-accelerating machines for nuclear physics research, and that grants of $£ 747,200$ had so far been made for running costs during the period August 1952-July 1957.

\section{Survey of Scientific Journals in the United States}

The report of a survey of the operations and finances of scientific journals in the United States has been published in a recent issue of Science (119, 357 ; 1954). The survey, by $R$. Tumbleson and Helen L. Brownson, is based on the 110 replies received to 205 questionnaires distributed by the National Science Foundation to a selected list of periodicals, with circulations ranging from five hundred to sixty thousand or more, seeking information regarding circulation, volume of original research papers published, papers awaiting publication, sources of revenue and expense items. No data are included for periodicals of the American Medical Association or the American Chemical Society ; but about 71 per cent of the replies related to the journals of scientific societies, and in this group 58 per cent of subscribers were members ; for periodicals with a circulation of four thousand or less, this figure was 50 per cent; for more than four thousand, 68 per cent. This group of periodicals published on the average nine hundred pages of original research material, or about 70 per cent of all papers submitted; many of the others were rejected because they were submitted to the wrong periodical. Seventy of these periodicals had a delay for accepted articles of less than six months; twenty-five, a delay of six months to a year, and five of a year or more, the average being $5 \cdot 3$ months for those publishing five hundred pages or less a year and 1.9 months for those publishing more than two thousand pages ; for periodicals publishing articles averaging four pages or less, the delay was 5.6 months compared with $2 \cdot 1$ months for those in which the average article was twenty pages or more. Subscriptions and society contribution in lieu of subscription represented $67 \cdot 2$ per cent of the income for periodicals with a circulation of less than a thousand, 69.8 per cent for those with a circulation of $1,000-7,999$, and $45 \cdot 2$ per cent for those with more than 8,000 ; advertising revenue was 0.7 per cent, 14.2 per cent and $51 \cdot 5$ per cent, respectively. Most editors disliked the idea of a direct subsidy from any sources, including the Federal Government, and many believed that additional income should be obtained from society memborship or advertising. Attention was directed to difficulties, expense and delay caused by bad writing and presentation.

\section{Lancaster Royal Grammar School: The New Biologian}

THE third issue of The New Biologian, the journal of the Natural History Society of Lancaster Royal Grammar School, has recently been published (June 1954). In the report of the Society's activities, by $P$. Brindley, it is recorded that a three-day exhibition was held in the biology laboratories, and several lectures given and films exhibited. P. F. Williams and P. E. Walker describe the bird-life of a hundredacre field, where they concentrated mainly on the two heronries. G. J. Beckett gives an illustrated account of fern-collecting in northern England : it is unfortunate that in the caption of one illustration 